\title{
MODERN FICTION AS FACTOR OF STUDENTS' READING CULTURE DEVELOPMENT
}

\author{
Galyna Bilavych \\ Vasyl Stefanyk Precarpathian National University, Ivano-Frankivsk, Ukraine \\ lapras1994@mail.ru
}

\author{
Iryna Rozman \\ Mukachevo State University, Mukachevo, Ukraine \\ rozmanii@ukr.net
}

\begin{abstract}
Nowadays there is an urgent need for the formation of students' reading culture in a modern university. It is necessary to enhance the educational value of a book in students, who are losing their interest in reading. Fiction is gradually becoming less popular among youth (as compared to cinema and music, it ranks third). This was confirmed by the results of the research conducted in 2012 and in 2016 at the Pedagogical Institute of Vasyl Stefanyk Precarpathian National University (PNU) and Pedagogical Faculty of Mukachevo State University (MSU). 78 students (majoring in Primary Education) and 30 students (majoring in Social Pedagogy) at PNU and 96 students at MSU were involved in the research. Most of the students were females. Applying such methods as questionnaires, conversations, interviewing and observations, we studied the place of fiction in the system of students' inquiries, its role in education, as well as students' knowledge of educational fiction. The whole complex of the methods used ensured the reliability of the research results and confirmed that students' reading culture is an integral part of the job profile diagram of a qualified teacher/educator. The level of students' reading culture may be enhanced in the case of implementing a specially organised system of teacher education. This system should enable students to acquire an awareness of the works by modern writers; introduce popular fiction books into students' extracurricular activity. In our opinion, student involvement in literary societies and research centres of modern literature may facilitate the formation of literary interests among future teachers.
\end{abstract}

Keywords: reading culture; future teachers; higher educational institution; educational fiction; reading culture.

\section{Introduction}

Scientists, educators, psychologists, sociologists and parents observe young people losing their interest in books, preferring their screen adaption. Reading fiction is being replaced with such entertainments as cinema, music, the Internet, television, etc. This statement has been supported by the results of the research carried out during 2012-2016 at the Pedagogical Institute of Vasyl Stefanyk Precarpathian National University (hereinafter PNU) and the Pedagogical Faculty of Mukachevo State University (hereinafter MSU). Thus, nowadays, literature as one of the genres of art ranks third among the students at PNU and MSU, and are inferior to cinema and music

Nowadays, the reading issue is discussed not only among educators, but also among officials and officers of line ministries. For example, the Ministry of Culture of Ukraine on September 13, 2016, declared the establishment of the Institute of the Book, whose mission is in promoting libraries, their transforming into cultural centres aimed popularisation of reading and promotion of book culture.

Besides, reading books is not only a way of spending leisure time, but also an important source of knowledge and intellectual development of personality. European researchers reasonably write about multidimensionality and polymorphism of modern literature and variety of modern works (Todorov, 2006, p.161).

The importance of solving this problem is associated with the contradictions between the requirements of intellectual and cultural development of future specialists and the declining of students' interest in the book as a source of knowledge and spirituality; the social need for training students to be active readers, and insufficient attention to that problem among educators.

Several publications have appeared in recent years documenting the importance of students' reading culture (e.g., Coyne, Kami'Enui, \& Carnine, 2007; Snow \& Sweet, 2003; Daniels \& Steres, 2015). The role of a book in the life of a personality has been gaining importance in recent years in different sciences such as literary studies, pedagogy, psychology, cultural studies, sociology, philosophy, etc. However, the role of modern fiction book having educational value, its influence on the formation of personality, promotion of the level of reading culture has not been outlined yet.

In this research, we hypothesise that students' reading culture is a key issue of their job profile diagram. We define reading culture as a complicated polystructural phenomenon involving knowledge, competences, skills, individual features necessary for future productive work. Therefore, the formation of reading culture should become a necessary component of training of a qualified and competitive professional. In our 
opinion, the level of students' reading culture will be considerably enhanced by providing a specially organised system of education. This system should provide:

a) students' awareness of modern writers and their works;

b) curriculum renovation in higher educational institutions by introducing popular modern books by Ukrainian and foreign authors;

c) introduction of popular fiction into students' extracurricular activity;

d) popularisation of modern books.

Under such conditions, an urgent necessity has emerged in enhancing the cultural and educational role of the book. We believe that modern popular books for children and youth, as a powerful factor of reading culture development, should play a leading role in the educational process.

\section{Methods}

The research was carried out on the basis of the Pedagogical Institute of PNU and Pedagogical Faculty of MSU in 2016. The research involved 78 third-year students (majoring in Primary Education) and 30 fourth-year students (majoring in Social Pedagogy) at PNU, and 96 students of the Pedagogical Faculty of MSU. Most of the students were females (94\% from PNU and 98\% from MSU).

Using the empirical methods (questionnaires, conversation, interviewing, observation), we studied the place of fiction in the system of students' inquiries, its role in the spiritual development of a personality, reading interests of future teachers, their knowledge of educational fiction, how fiction reflects modern pedagogical problems, especially such a phenomenon as bullying. Then, using a statistical approach, we processed the results of the research. Such methods as analysis and synthesis, system-based structural method, simulation, classification etc. gave us the opportunity to determine reading interests of students, find out their levels of reading culture and create a model for its developing by means of popular modern books for children and youth. The whole complex of methods used ensured the reliability of the research results. Besides, it was possible for us to compare the results of the present year's research with those obtained in 2012 at the Pedagogical Institute of PNU. Thus, we had an opportunity to follow the development trends of students' reading interests and introduce changes into the development pattern of their reading culture.

\section{Results}

The results of our research show that current massive computerization of society has influenced the modern culture-making process. Nowadays in the Ukrainian society, there is a tendency of a practical attitude towards the book and lowering youth reading interests. So, in comparison with 2012, the "love of reading" index among the students at PNU was reduced from $82 \%$ to 55\% (among the students at MSU, this index is lower $-40 \%$ ). The analogous changes also took place in such a sphere as students' leisure. In 2012, in response to the question "How do you spend your spare time?" $70 \%$ of the respondents claimed that they read fiction. In 2016, this index was reduced to 50\%, however, $35 \%$ of the students stated that they "actively use social networks and communicate with their friends via the Internet" (in 2012, this index was 20\%).

We think that there are a number of social and cultural reasons for decreasing book readership: a vast amount of information, rapid development of the Internet, dominance of cinema culture, high price for books, insufficient popularisation of modern books for children and youth, etc. The reduction of students' spare time has resulted in the transformation of reading from the process of self-education into a casual event not requiring special efforts. The forms of activities assigning readers a role of a passive information recipient are not effective anymore. Due to computerization, the educational function of the book does not play a great role anymore. Modern students find reading scientific journals, newspapers and Internet sources to be more important than fiction, that is why the book is gradually losing its significance in the spiritual, aesthetical and educational context, it is ceasing to be a predominant tool of education and a source of spiritual development.

A noteworthy detail is that according to the questionnaire results, a phenomenon of "antibookaholism" is emerging (30\% at MSU and $22 \%$ at PNU) which raises the problem concerning the development of reading culture among students.

As distinct from the results of research conducted in 2012, when $100 \%$ of the respondents stated that they preferred paperback books, nowadays $25 \%$ of students prefer electronic books and audiobooks.

The students' answers to the question on their library attendance (university, regional, youth etc.) showed that $28 \%$ of the future teachers at PNU and $35 \%$ of the respondents at MSU do not go to the libraries at all.

Besides, we have analysed reading interests of the students at PNU and MSU. They are substantially the same. The young people prefer detective novels (40\%), science fiction (20\%), historical novels (20\%) and adventure books $(20 \%)$. 
It is interesting to know that the students of both higher educational institutions consider fiction to be an education tool. However, there is a certain contradiction. The majority of our respondents $(60 \%)$ could not give any examples of fiction books where the issue of education was raised. The students mistakenly (40\%) classified pedagogical works ("The Big Didactics" by Yan Amos Komenský (30\%), "Swansong" by Johann Heinrich Pestalozzi (30\%) and other pedagogical literature, as textbooks). One of the respondents pointed out that practically "all classic Ukrainian and foreign literature have educative content". The students at MSU classified such books as "Emile, or On Education" by Jean-Jacques Rousseau (20\%), "The Land" by Olga Kobylianska (10\%), "The Adventures of Oliver Twist" by Charles Dickens (20\%), "The Little Prince" by Antoine de Saint-Exupery (20\%), "Divergent" by Veronica Roth $(20 \%)$ and "Do the Oxen Bellow, When Their Mangers Are Full?" by Panas Myrny (10\%) as educational fiction. The majority of future primary school teachers studying at PNU could not mention the books of this category.

However, the social pedagogy students (PNU) indicated that such modern fiction books as "Red" by Andrii Kokotiukha, "To Have Everything", "Village Is Not People", "Following the Smell of Meat" by Lyuko Dashvar, "Raven" by Vasyl Shkliar, "When You Are Near" by Svitlana Talan, "The Sinner" by Olena Pechorna, "Girl on the Balloon" by Olha Sloniovska, "Veronika Decides To Die" and "The Devil and Miss Prym" by Paulo Coelho can be referred to those of pedagogical content. One of the students called the book "365 Short Stories for the Soul" by Italian Catholic priest and author Bruno Ferrero a "modern pedagogical chrestomathy" that deals with "practically all the aspects of personality education". The future social pedagogues emphasised that Bruno Ferrero's books, as well as such popular scientific works as "The 10 Most Common Mistakes Good Parents Make: And How to Avoid Them" by Kevin Steede, "How to Stop Worrying and Start Living" by Dale Carnegie, "We and Our Chindren" by Boris Nikitin and Lena Nikitina, "Games People Play" by Eric Berne, "The Doctor and the Soul" by Victor Frankl are worth profound studying at university by introducing them into the courses of pedagogical cycle. Such literary competence of the social pedagogues is foremost explained by their participation in our problem-oriented science group called "Social and educative issues in modern fiction" on the one hand and our efforts towards their motivation for reading on the other hand. The students participate in the socialisation processes: formation of one's outlook, needs for education and self-education, vocational development.

\section{Discussion}

Nowadays scientists consider a book as an information component of society development. It is an integral part of culture-making process in general and personality education in particular (Bilychenko, 2015, p. 4). We support the statement that a book, in its traditional form, is a prevailing factor of cultural communication in Ukraine (Bilychenko, 1999, p. 305). Our research indicates that a number of students reading e-books ( $25 \%$ of the respondents) is growing. Thus, for the Ukrainians, a book, being a source of spirituality, is a component of culture development.

However, according to the results of our research, due to different reasons, students are losing interest in fiction. In a higher school, the range of reading interests among youth becomes narrower, and the majority of students pay no attention to the huge potential of modern pedagogical fiction.

These changes were predicted by the famous educator and humanist Vasyl Sukhomlynskyi in his article "Path to the Blooming Garden" (Sukhomlynskyi, 1976, p. 180). He warned about children's obsession with audiovisual media, highlighted the issues of reading culture formation, literary development, and worked out the problem of Word and Beauty as the major tools of education.

The above-mentioned issues raise the need for student's reading culture enhancement. We believe that the key role in this process should be assigned to a modern popular fiction book having educational content. In our opinion, student involvement in literary societies, research teams and research centres of modern literature would facilitate the formation of literary interests among future teachers. For example, nowadays this work is actively performed by Ivano-Frankivsk branch of Ukrainian Research Centre for Children's and Youth Literature (head - Dr. T.Kachak) where students are involved in reading and analysis of literary works, write critical articles, reviews, feedbacks, essays and scientific papers, meet modern writers.

While teaching the disciplines "Foreign Literature" and "Children's Literature" to future primary school teachers at MSU, we draw student's attention to pedagogical fiction. Students point out the pedagogical problems that foreign writers highlight in their works (for example, "A Perfectly Ordinary School" by Jeremy Strong, "Hurra for Ludvig Lurifax" by Jan-Olof Ekholm, "Nina - The Girl from the Sixth Moon" by Muni Vitcher, "The Glassblower's Children" by Maria Gripe, "The Thinker Acts" ("Der Denker greift ein") by Christine Nostlinger, etc.). We always announce new fiction books for children and youth; systematically hold literary reviews, etc. It is essential for the teachers themselves to be active readers and bibliophiles. Only, in that case, they are able to demonstrate a "book fashion" to their students. Libraries, acting in close 
cooperation with teachers, should create proper environment aiming at the formation of literary culture among students.

Having analysed the research results, we observe a contradiction in the higher educational practice. On the one hand, students note that modern literature raises important and relevant problems of the present, for example bullying (about $60 \%$ of the students of both higher educational institutes properly explained this phenomenon as "mocking weak people", "baiting weak people", "moral and physical humiliation", "violence against people" etc.). On the other hand, only $20 \%$ of the respondents at PNU (majoring in Social Pedagogy) provided examples of modern works where this problem is highlighted ("The Outcast" and "Stranger" by Serhiy Hrydin, Harry Potter series by Joanne Rowling, etc.).

It should be noted that nowadays the problem of violence against children and women within the family has attracted scientists' attention worlwide. For example, in the USA and Western Europe, the first works on this problem appeared in the 1970s. They were followed by a variety of social programmes to prevent violence. In Ukraine, the issue of violence in a family has not been the subject of special research among educators, sociologists, psychologists and social workers for a long time. In our opinion, not enough attention has been paid to violence preventing measures. Content, forms and methods of social work are not properly revealed. There is no objective official statistics of violence against children either. Public attention to this problem is not sufficient. Modern fiction has huge potential possibilities in this area, for example, "The Casual Vacancy", a novel written by Joanne Rowling (2013) where the author raises the most relevant issues not only in the scope of English schooling, but in education on a global scale. In her novel, Rowling describes various problems of modern society, in particular, violence against children (physical, sexual, moral and psychological), bullying, conflicts between children and parents (generation conflicts), biased attitude to children from dysfunctional families, antisocial events, suicide problems among teenagers, etc.

Rowling (2013) emphasizes that such terrible social and pedagogical wounds should be immediately treated in a therapeutic way. If the community does not pay attention to the problem of violence against children in a proper time, they will pay dearly for it with lives and health of innocent children. Thus, fiction books could be considered as peculiar pedagogy manuals where a reader looks for answers to urgent and global pedagogical problems of the present.

It is important to note that educators, community and educational institutions worldwide have developed a system of measures aimed at preventing and eliminating bullying. For example, in 2006, the Ministry of Education of Great Britain elaborated recommendations and strategies to stop bullying in secondary schools. In Ukrainian scientific literature, this problem has been revealed in the works of Lushpai (2010; 2013).

\section{Conclusions}

The issue of literary culture development in modern conditions, on the one hand, is insufficiently reflected in scientific works; there are no appropriate educational and methodical recommendations available. On the other hand, this problem is of particular importance nowadays in the age or rapidly developing telecommunications and computer technologies.

In any of its forms (classic or electronic), a book still remains a cultural agent and performs its educational function. However, due to the acceleration of society computerization, new methods and forms of raising motivation for reading among students should be searched for. There are a number of reasons for declining level of literary development in society. Cinema, television, computer, and the Internet, involving students in the virtual reality, slowly but confidently put them off the book. On the basis of our research, we can claim that the student community is gradually entering the completion of "book era", which is disturbing and worth considering by university teaching staff. Due to the rapid development of the Internet, reading fiction books has been reduced abruptly resulting in the low level of students' literary development, and consequently, their low level of vocational development as the reading culture is considered as an integral part of the future teacher's job profile diagram.

There are some typical mistakes occurring in educational practice. For example, instead of continuous conversations with students on the importance of reading, it is necessary to engage teenagers in a systematic educational activity, acquainting them with a wide range of popular modern books for children and youth. In our opinion, educational fiction, displaying school life, relations between parents and children, antisocial events, the inner world of a child may lead to the formation Christian, moral and ethical, as well as artistic and aesthetic values. Thus, the books having educational content could be fairly called tutorials where training methods, principles and forms of education, school management can be found.

On the basis of the results of the research done, we came to the conclusion that the optimal way of the improvement of traditional methods for developing students' reading culture is to implement reading modern educational fiction books in the educational process at higher educational institutions. This work largely 
depends on teachers' literary experience, their profound knowledge of modern popular books. The effective means and forms of the development of reading culture among future educators could be scientific groups; problem-oriented groups specialized in learning modern popular books for children and youth; research centres, etc. These activities would improve students' reading culture and lead to their vocational development.

\section{References:}

Bilychenko, O.L. (1999). Zberihannia ta zastosuvannia kulturno-vykhovnoi roli knyhy [Preservation and Using of Cultural and Educational Role of the Book]. Humanization of educational and training process, 1(5), 304-307.

Bilychenko, O.L. (2015). Osoblyvosti ukrainskoi khudozhnoi literatury v kulturi suchasnoho informatsiinoho suspilstva. [Features of Ukrainian Fiction in Culture of Modern Knowledge Society]. Naukovi zapysky Mizhnarodnoho humanitarnoho universytetu, 1(15), 4.

Coyne, M. D., Kami'enui, E. J., \& Carnine, D. W. (2010, July). Current issues in reading comprehension. Pearson Allyn Bacon Prentice Hall. Retrieved from http://www.education.com/reference/article/current-issues-reading-comprehension/

Daniels, E. \& Steres, M. (2015). Examining the Effects of a School-wide Reading Culture on the Engagement of Middle School Students. Research in Middle Level Education Online, 35. https://doi.org/10.1080/19404476.2011.11462085

Lushpai, L.I. (2010). Bullinh yak sotsialno-pedahohichna problema ta shliakhy yii vyrishennia (na prykladi dosvidu serednikh zahalnoosvitnikh shkil Velykoi Brytanii) [Bullying as Social and Educational Problem and Ways of its Resolving (in Terms of Experience of Secondary Schools of Great Britain)]. Ukrainoznavchyi almanakh, 1(4), 126-131.

Lushpai, L.I. (2013). Shkilnyi bullinh yak riznovyd suspilnoi ahresii [Bullying in Schools as a Form of Social Aggression]. Proceedings of The National University of Ostroh Academy, 1(33), 85-89.

Rowling, J.K. (2013). The Casual Vacancy (V.Morozov, T.Malkovych Trans). Kyiv, Ukraine: A-BA-BA-HA-LA-MA-HA

Snow, C., \& Sweet, A. (2003). Rethinking Reading Comprehension. Solving Problems in the Teaching of Literacy. A. P. Sweet \& C. E. Snow (Eds.). NY: The Guilford Press.

Sukhomlynskyi, V.O. (1969). Stezhka do kvituchoho sadu [The Path to the Bloomy Garden] (Vols 1-5). Literaturna Ukraina, 26. IX. Todorov, Ts. (2006). Ponyattya literatury ta inshi ese [The Notion of Literature and other Essays] (Ye. Marichev, Trans.). Kyiv, Ukraine: KM Akademiia. 